\title{
COVID-19 causes unprecedented educational disruption: Is there a road towards a new normal?
}

\author{
Hans d'Orville ${ }^{1}$
}

Published online: 3 June 2020

(C) UNESCO IBE 2020

\begin{abstract}
COVID-19 confronts the education system with a new and massive crisis. What should a "new normal" look like for future generations? How can countries use the innovativeness of the recovery period to "build back better"? This Viewpoint highlights the UNESCO-led Global Coalition for Education initiative, which is seeking solutions to support learners and teachers, as well as governments throughout the recovery process, with a principal focus on inclusion, equity, and gender equality. The Viewpoint also argues that the current crisis is an opportunity for stronger international collaboration, which might provide a better focus and deliver solutions, including digital tools. Resilience and adaptability will be crucial for the next generations to navigate through the present-and any future-pandemic.
\end{abstract}

Keywords Pandemic $\cdot$ Learning crisis $\cdot$ School closures $\cdot$ Digital learning tools · International cooperation

Even before the outbreak of the global COVID-19 pandemic, the world was already confronting a "learning crisis" (UNESCO 2013; World Bank 2019); it was also off track to meet Sustainable Development Goal (SDG) 4, which enjoins all countries to ensure that all girls and boys complete free, equitable, and quality primary and secondary education (UIS 2019). With the spread of the virus, the education system is now facing an entirely new and massive crisis. According to UNESCO (2020a), more than $87 \%$ of the world's student population-over 1.5 billion learners in 165 countries-have been affected by the temporary closure of educational institutions. Not since World War II have so many countries around the world seen schools and educational institutions go into lockdown at around the same time and for the same reason.

Extended school closures may not only cause loss of learning in the short term, but also diminish human capital and economic opportunities for children and youth over the

Hans d'Orville

Paris, France 
long term. Globally, school closures disproportionately hurt vulnerable and disadvantaged students who rely on schools for a range of social services, including health and nutrition. But their impact on education is likely to be most devastating in countries with already low learning outcomes, high dropout rates, and low resilience to shocks.

Faced with that situation, UNESCO is launching a Global Education Coalition (UNESCO 2020b). The Coalition is a call for coordinated and innovative action, seeking solutions that will not only support learners and teachers but also governments throughout the recovery process, with a principal focus on inclusion, equity, and gender equality. It comprises multilateral organizations, including the International Labor Organization, the UN High Commission for Refugees, the United Nations Children's Fund (UNICEF), the World Health Organization, the World Bank, the World Food Programme, and the International Telecommunication Union, as well as the Global Partnership for Education, Education Cannot Wait, the Organisation Internationale de la Francophonie (OIF), the Organization for Economic Cooperation and Development (OECD), and the Asian Development Bank.

Private sector companies, including Microsoft, GSMA, Weidong, Google, Facebook, Zoom, KPMG, and Coursera have also joined the Coalition, contributing their resources and expertise. Likewise, philanthropic and non-profit organizations, including the Khan Academy, Dubai Cares, Profuturo, and Sesame Street are also part of the Coalition. Media outlets like BBC World Service have also joined to counter the adverse impact of the global lockdown.

Education could have benefited from better and more digital education solutions during the coronavirus crisis; thus, it is time to reflect on the role digital technology should have in the future of education. Governments and educational authorities have been deploying distance learning solutions: delivering content, supporting teachers, providing guidance to families, and addressing connectivity challenges in order to facilitate online instruction and distribution of learning material. But a danger looms: a new type of digital divide is bound to arise as students need laptops, tablets, or phones, as well as some type of internet access, in order to benefit from access to online material.

The pandemic offers an opportunity for investments in education at all levels, to transform education and "leave no one behind", as envisaged in the SDGs. The Coalition will endeavor to match needs with free and secure solutions, to provide digital tools and learning management solutions, to upload national digitized educational resources, to curate resources for distance learning, and to strengthen technical expertise. Support to systemic education reform, in particular through effective guidelines and careful plans for reopening, will be equally crucial to ensure that when children do return to school, schools can adapt their classrooms and methods to provide the necessary safe environments for learners.

The return to school and universities is being put in motion in a staggered manner and according to the disinfection protocols of the school buildings. Certain age groups and classes will return earlier than others and significant differences will exist, both within contiguous regions and within individual countries. There is no size that will fit all. But there is also no dispute that schools should reopen in a measured manner. The honorary Inspector-General for Education in France, Jean-Paul Delahaye, supports this policy, calling another five or six months without school an unmitigated catastrophe in waiting (Le Monde 2020).

A shift to some online tools could change teachers' roles, making them more like coaches and mentors. Digital technology has made tremendous progress in the design of "personalized" solutions based on each student's knowledge and learning styles. Further, digital personalization systems can help teachers and other educators, including parents, accomplish their educational routines by other means. 
The coronavirus crisis has made the importance of digitalisation and AI in education more obvious. AI and other digital systems are tools augmenting our human capacity. What we achieve with them really depends on how we use them. There is a risk that educational AI systems and personalisation could increase inequities: after the coronavirus crisis, they could become high-priced commercial services affordable only to a small share of the population. This would induce a new digital divide.

In a report titled "The COVID-19 pandemic: Shocks to education and policy responses", the World Bank observed: "Before the pandemic, 258 million children and youth of primary- and secondary-school age were out of school and low schooling quality meant many who were in school learned too little. Even worse, the crisis was not equally distributed. The most disadvantaged children and youth had the worst access to schooling, highest dropout rates, and the largest learning deficits" (World Bank 2020). The pandemic is now threatening to make these outcomes even worse. In the words of Jaime Saavedra, the Bank's Global Director for Education, "the pandemic has already had profound impacts on education by closing schools almost everywhere in the planet, in the largest simultaneous shock to all education systems in our lifetimes. The damage will become even more severe as the health emergency translates into a deep global recession" (World Bank 2020).

The virus-induced disruption offers an opportunity for all actors in the education sector to rethink the system and discuss how to educate future generations. As educators grapple with new ways of communicating with students away from classrooms and lecture theatres, it is a good time to reflect on how this disruptive crisis can help define what a "new normal" for learning should look like.

Countries should use the focus and innovativeness of the recovery period to "build back better". The key is not to replicate the apparently vulnerable pre-COVID systems, but instead to build improved systems that allow accelerated learning for all students, drawing on digitized approaches. When people lament "things will never be the same", they are talking about something deeper-about our habits, norms, and ways of living. Some aspects of schooling may well not go back to the way they were before.

The closure of schools, colleges, and universities does not only interrupt teaching: it also coincides with a key assessment period, and baccalaureate tests and exams have been postponed or cancelled in many countries. In higher education, many universities and colleges are replacing traditional exams with online assessment tools. This is a novel experience for both teachers and students, and as a result such assessments will likely have larger measurement errors than usual.

The careers of this year's university graduates may likewise be severely affected by the COVID-19 pandemic. They have experienced major interruptions in the final part of their studies, they are experiencing major interruptions in their assessments, and finally they are likely to graduate at the beginning of a major global recession. Evidence suggests that poor market conditions at labour market entry cause workers to accept lower-paid jobs, which may have permanent negative effects for the careers of some students.

The majority of students in today's educational institutions are from Generation Z, a generation that has grown up in a truly globalized world and is deeply intertwined with technology. This generation, the oldest of whom are now 25 years old, must reflect on their education in the context of a truly global pandemic, with many students facing cancelled exams, sporting events, and even graduation celebrations. Generation Z students are used to instant communication and feedback, effected through apps like Facebook Messenger, Snapchat, WhatsApp, WeChat, and Zoom. But they also see the power of working collaboratively to solve the world's biggest challenges: their agenda not only engages COVID-19 but crises in climate change and mental health (World Economic Forum 2020). 
By comparison, Generation Alpha-the children of millennials-is the most racially diverse generation across the world. For them, technology is simply an extension of their own consciousness and identity, with social media being a way of life. According to a Dell Technologies (2017) report, 85\% of the jobs that Generations Z and Alpha will start in 2030 have not been invented yet. $65 \%$ of primary-school children today will be working in job types that do not exist yet. These young pre-schoolers are also the generation with the most nontraditional family structures. While many Alpha learners are likely oblivious to COVID-19's impact on their education, they will surely feel it for years to come.

Finally, this crisis is a new opportunity for international collaboration. Stronger international cooperation-involving governments at different levels, companies, and international public-private partnerships - might help provide a better focus, deliver solutions and generate common digital goods. The COVID-19 crisis may well change our world and our global outlook; it may also teach us about how education needs to change to be able to better prepare young learners for what the future might hold. This is the challenge for the Global Education Coalition.

Resilience and adaptability will be crucial for the next generations. Future employers will highly value creativity, communication, and collaboration, alongside empathy and emotional intelligence. We also need to train students to work across demographic differences, so as to harness the power of the universal collective through effective teamwork and global collaboration. The corollary of such education is pursuing multilateralism in all fields of human activities, especially in the interconnected world we are inhabiting, as so tragically evidenced by COVID-19. No doubt, these skills are essential to navigate the present pandemic — and to prepare for the next one.

\section{References}

Dell Technologies (2017). Realizing 2030: A divided vision of the future. https://www.delltechnologies.com/ content/dam/delltechnologies/assets/perspectives/2030/pdf/Realizing-2030-A-Divided-Vision-of-theFuture-Summary.pdf.

Le Monde (2020). Cinq à six mois sans école, c'est une catastrophe annoncée. https://www.lemonde.fr/societe/ article/2020/05/23/cinq-a-six-mois-sans-ecole-c-est-une-catastrophe-annoncee_6040505_3224.html.

UIS [UNESCO Institute for Statistics] (2019). The world is off track to deliver on its education commitments by 2030. Blog entry by Manos Antoninis, Director of the Global Education Monitoring Report, and Silvia Montoya, Director of the UNESCO Institute for Statistics. Montreal: UIS. https://sdg.uis.unesc o.org/2019/07/09/the-world-is-off-track-to-deliver-on-its-education-commitments-by-2030/.

UNESCO (2013). The global learning crisis: Why every child deserves a quality education. Paris: UNESCO. https://unesdoc.unesco.org/ark:/48223/pf0000223826.

UNESCO (2020a). COVID-19 educational disruption and response. Paris: UNESCO. https://en.unesco.org/ covid19/educationresponse.

UNESCO (2020b). Global education coalition. Paris: UNESCO. https://en.unesco.org/covid19/educationr esponse/globalcoalition.

World Bank (2019). The education crisis: Being in school is not the same as learning. Washington, DC: World Bank. https://www.worldbank.org/en/news/immersive-story/2019/01/22/pass-or-fail-how-can-the-world -do-its-homework.

World Bank (2020). The COVID-19 pandemic: Shocks to education and policy responses. Washington, DC: World Bank. https://openknowledge.worldbank.org/handle/10986/33696.

World Economic Forum (2020). 4 ways COVID-19 could change how we educate future generations. https:// www.weforum/agenda/2020/03/4-ways-covid-19-education-future-generations.

Publisher's Note Springer Nature remains neutral with regard to jurisdictional claims in published maps and institutional affiliations. 
Hans d'Orville (Germany) is former UNESCO Assistant Director-General for Strategic Planning; IBE Senior Fellow; Honorary Professor, South China University of Technology, Guangzhou; Chairman, Advisory Committee, International Center for Creativity and Sustainable Development (ICCSD), Beijing. 